\title{
Comments on the use of chemically based mixing models in glacier hydrology
}

\author{
MARTIN SHARP, \\ Department of Geography, University of Alberta, Edmonton, Alberta T6G 2H4, Canada \\ Giles H. BROWN, \\ Centre for Glaciology, Institute of Earth Studies, University of Wales, Aberystuyth, Dyfed Sr23 3DB, Wales \\ MARTYN TRANTER, \\ Department of Geography, University of Bristol, Bristol BS8 1SS, England \\ IAN C. Willis, \\ Department of Geography, Universily of Cambridge, Cambridge CB2 3EN, England \\ BRYN HUBBARD \\ Centre for Glaciology, Institute of Earth Sciences, University of Wales, Aberystwyth, Dyfed Sr23 3DB, Wales
}

\begin{abstract}
The assumptions involved in the use of chemically based mixing models for analysis of flow routing of meltwaters in glacierized basins are critically evaluated. The assumption that glacial drainage systems consist of only two primary flow components is arbitrary and must be supported by independent evidence. Recent studies of the processes by which meltwaters acquire solute indicate that the assumption that flow components have unique and constant chemical compositions is unlikely to be correct. Source-water composition and weathering potential will vary over the course of a melt season, and the extent of subglacial weathering is strongly dependent upon such factors as meltwater residence time and the availability of reactive sediment, both of which are known to vary on diurnal to seasonal time-scales. Mixing of flow components does not appear to be confined to the terminal regions of glaciers and is therefore unlikely to be conservative as assumed. A multi-parameter mixing model is applied to the analysis of data on the chemistry of waters sampled from boreholes drilled through Haut Glacier d'Arolla, Switzerland, to demonstrate the range of dissolved species for which the assumption of conservative mixing is violated. The consequences of this violation for quantitative hydrograph separation are shown to be highly significant. The utility of mixing models as a tool for the investigation of glacier hydrological systems is questionable and the results of previous studies are unreliable.
\end{abstract}

\section{INTRODUCTION}

A recurrent theme in research on glacier hydrology has been the use of measurements of meltwater quality to derive information about the character of subglacial and englacial drainage systems Collins, 1978, 1979; Oerter and others, 1980; Collins and Young, 1981; Gurnell and Fenn, 1984; Sharp, 1991; Tranter and Raiswell, 1991; Lecce, 1993). One technique which has been widely adopted in these studies and used to make quantitative inferences about meltwater fluxes through the different elements of such drainage systems is the chemically based mixing model (Pinder and Jones, 1969). This technique is used to separate meltwater run-off hydrographs into components which allegedly arise from flow through two (or sometimes three) elements of the drainage system. The technique makes a number of assumptions about the nature of englacial/subglacial drainage systems and the manner in which meltwaters acquire their solute load, most of which have not been tested in previous studies. Recent developments in our understanding of the nature. and behaviour of glacier drainage systems (Nienow and others, in press), and of chemical weathering processes in glacial environments (Tranter and others, 1993), cast considerable doubt on the validity of these assumptions and thus on the application of the method. The purpose of this note is to draw attention to the nature of these assumptions, to present some of the data which challenge their validity and to examine their implications for quantitative hydrograph separation. It is prompted by a recent application of the mixing-model method (Lecce, 1993), which, like previous studies, draws conclusions 
which we do not believe are sustainable in the light of the information presented.

\section{ASSUMPTIONS OF CHEMICALLY BASED MIXING MODELS}

Collins $(1978,1979)$ argued that a simple mixing model of the form:

$$
Q_{\mathrm{t}} C_{\mathrm{t}}=Q_{\mathrm{s}} C_{\mathrm{s}}+Q_{\mathrm{e}} C_{\mathrm{e}}
$$

could be used to separate meltwater-discharge hydrographs into two flow components. Here $Q$ refers to meltwater discharge and $C$ to solute concentration. The subscripts $t, s$ and e refer to the total flow, and to what Collins termed the "subglacial" and "englacial" components. Collins assumed that waters which pass more slowly through the system ("subglacial" waters) experience considerable enrichment as a result of contact with subglacial bedrock and finely comminuted rock debris. $\mathrm{He}$ also assumed that these two types of water mixed in a region close to the glacier snout, the englacial waters diluting the subglacial waters to produce bulk meltwaters with a chemical composition dependent upon the initial chemistries of the two components and their mixing ratio (the relative proportions of the two components in bulk waters). If the chemical composition of the components is known, the mixing-model equation can be rewritten to allow solution for the component discharges:

$$
Q_{\mathrm{s}}=\left[\left(C_{\mathrm{t}}-C_{\mathrm{e}}\right) /\left(C_{\mathrm{s}}-C_{\mathrm{e}}\right)\right] Q_{\mathrm{t}} .
$$

Models of this form make a number of assumptions which we now examine.

\section{Two drainage components}

An immediate problem concerns the definition of the flow components. Collins envisaged two principal drainage routeways through a glacier - a system of major channels which allows rapid transit and isolates waters from potential solute sources, and a system which permits much slower transit and brings waters into contact with solute sources. The first he defined as the "englacial" component, even though it was said to drain via a system which includes "arterial conduits located at the bed", (Collins, 1979, p. 349), and the second as the "subglacial" component, which was said to drain via "channels which may be moraine-walled or cut in bedrock, and in which sediment transport occurs" (Collins, 1979, p. 349). This use of the terms "subglacial" and "englacial" to describe the flow components is misleading, since both can apparently drain through channels located at the glacier bed. The actual basis for distinguishing between the two components is the residence time of meltwaters at the glacier bed rather than their location or morphology. In this sense, it would seem more logical to differentiate the components using terms such as delayed flow and quick flow (cf. Tranter and others, 1993). Nevertheless, we retain Collins' terminology for the purposes of the present discussion.

Collins' definition of the hydrological pathways followed by the two components is vague, since icewalled conduits at the glacier bed will presumably also have bedrock or morainic floors, and it is not clear why, given the definitions presented, the two pathways would result in systematic variations in residence time within the glacier. Equally, whilst it is clear that Collins envisaged the source of "englacial" waters to be surface melting, it is not clear what source he envisaged for "subglacial" waters. The source would presumably be surface melt, internal/subglacial melt or ground water. Which of these is actually the source has major implications for flux magnitudes, patterns of flux variation in time and component chemistries. A more rigorous definition of the morphology of the hydrological pathways followed by the two flow components is required if the results of mixing-model calculations are to be interpreted. Theoretical analyses of glacier hydrology now identify at least seven possible components to subglacial and englacial drainage systems. These include englacial conduits, subglacial water films (Weertman, 1972), R-channels incised upwards into the glacier sole Röthlisberger, 1972), Nye channels incised into bedrock (Nye, 1973), linked-cavity systems (Walder, 1986), permeable subglacial sediments (Shoemaker, 1986) and broad canals incised into the surface of such sediments (Walder and Fowler, 1994). Given this diversity, it seems arbitrary and unreasonable simply to assume that the drainage system of a given glacier contains only two (or perhaps three) primary components. There is clearly a need for applications of the mixing-model technique to be supported by independent evidence (such as is provided by intensive dye-tracing or borehole-based studies) for the character of the subglacial drainage system.

Where multiple components do exist within a drainage system, it is important to understand how they are arranged in space and how they are interconnected. Failure of the drainage sytem to conform to the assumption that the hydrological pathways represented in the mixing model are arranged in such a way that mixing is confined to the terminal regions of the glacier has important hydrochemical implications. Where two distinct drainage pathways do exist, field evidence suggests that the slower one may be located up-glacier of the faster, so that "subglacial" waters actually pass along the same path as "englacial" waters in the lower glacier (Humphrey and others, 1986; Nienow and others, in press). If this is so, there would be considerable scope for continued chemical evolution of the combined waters after mixing. Such evolution would violate the assumption of conservative mixing (all solute transported by the bulk meltwaters is derived directly from the flow components) made by mixing models (see below).

Where mixing models have been applied to the interpretation of run-off data collected over whole melt seasons (Gurnell and Fenn, 1984), or large parts thereof, the use of a model with a single form is tantamount to assuming that the structure of the drainage system is constant over time. This assumption is directly contradicted by the results of dye-tracing studies which indicate significant changes in drainage-system structure over individual melt seasons (Willis and others, 1990; Hock and Hooke, 1993; Nienow, 1994). Since these structural changes are often manifested most clearly by changes in 
meltwater residence time, they have profound implications for the processes and magnitude of solute acquisition by meltwaters, and thus for the assumption made in most mixing-model studies that component chemistries are unique and constant over time (see below).

\section{Unique component chemistries}

In most applications of the mixing model published to date (e.g. Collins, 1978, 1979; Gurnell and Fenn, 1984), it has been assumed that the chemical composition of the "subglacial" and "englacial" components is constant, and that variations in bulk meltwater chemistry reflect variations in the mixing ratio of the two components (an exception to this is the work of Tranter and Raiswell (1991)). Collins (1979) justified this assumption on the grounds that (a) the drainage pathways followed by "englacial" waters are essentially free of solute sources, and (b) that solute acquisition in the pathways followed by "subglacial" waters is sufficiently rapid to bring them to a uniform equilibrium concentration. Neither argument is convincing. Collins' "englacial" waters are derived largely from melting of surface snow and ice. It is well known that impurities held within a snowpack are not released in meltwater at a uniform concentration corresponding to their bulk concentration within the snow, but that they are released at significantly higher concentrations within the first meltwater produced (Johannessen and others, 1977). The chemistry of such waters will therefore vary over a melt season in response to this leaching effect. Seasonal changes in the acidity of source waters will also impact on their ability to acquire solute by weathering of subglacial sediment, as demonstrated by laboratory weathering experiments Brown and others, in press).

Experimental studies of solute acquisition from glacial flour by dilute aqueous solutions (Tranter and others, 1989; Brown and others, in press) indicate that, although rates of acquisition decrease exponentially over time, they are nevertheless still significant after periods of time comparable with meltwater residence times in glaciers indicated by dye-tracing experiments Collins, 1982; Burkimsher, 1983; Seaberg and others, 1988; Willis and others, 1990; Fountain, 1993; Hock and Hooke, 1993; Nienow, 1994). Thus, if meltwaters come into contact with suspended sediment or other rock material during their transit through a glacier, they are likely to experience significant enrichment in solutes. Since both residence time and suspended-sediment concentration vary with meltwater discharge (Burkimsher, 1983; Gurnell, 1987), the degree of enrichment is likely to vary over time, producing variations in meltwater chemistry which are not directly attributable to the mixing ratio (Brown and others, 1994). The kinetics of the weathering processes are such that the impact of such variations on solute acquisition will be greatest in major subglacial channels where significant suspended-sediment transport occurs. When dilute waters are placed in contact with suspended sediment, solute-acquisition rates are initially rapid but they decline exponentially over time (Brown and others, in press). Thus, a given change in water-sediment contact time will have maximum impact on solute acquisition when the average contact time is short. Dye-tracing studies indicate that this is usually the case in major subglacial channels.

The consequence of assuming constant-component chemistries, when these are in fact variable, is that variations in component chemistry will be expressed as variations in the mixing ratio in the mixing-model results. For instance, increased solute concentrations in bulk waters, such as occur under recession-flow conditions, would normally be interpreted as resulting from an increased proportion of "subglacial" waters in bulk runoff. In reality, they may be at least partly attributable to "subglacial" waters becoming more concentrated over time as discharges decrease and residence times consequently increase. If such artefacts, which may involve both the magnitude of the component discharges and their pattern of variation over time, are to be avoided, it is necessary to determine accurately the chemistries of the components and their temporal variability. Tranter and Raiswell (1991) suggested a method for doing this using measurements of the properties of bulk meltwaters, but direct measurements in the subglacial environment would be preferable.

A further problem with the assumption of constant meltwater chemistry relates to the choice of appropriate concentration values for each component. Various suggestions have been made concerning which values should be used. For the "englacial" component, these include the concentration of a species in supraglacial waters and the minimum concentration in bulk meltwaters recorded during a melt season. For the "subglacial" component, they include the concentration in ground-water springs, winter base flow or summer recession flows (see Fenn (1987) for a review). Each of these possibilities will result in a different value for the component chemistry, which will affect both the magnitude and temporal pattern of flow calculated for each component (Brown and Tranter, 1990). Higher values of $C_{\mathrm{s}}$ and/or $C_{\mathrm{e}}$ will reduce $Q_{\mathrm{s}}$, though the effect of varying $C_{\mathrm{e}}$ is less marked because $C_{\mathrm{e}}$ occurs on both sides of Equation (2). Choice of an appropriate value for $C_{\mathrm{e}}$ is, however, critical at times when $Q_{\mathrm{e}}$ comprises the majority of bulk meltwaters. We have particular concerns about the use of maximum and minimum solute concentrations in bulk run-off to characterize the compositions of the flow components because, during the summer of 1993, we regularly sampled waters from the base of boreholes at Haut Glacier d'Arolla, Switzerland, which were up to three times more concentrated than any which drained from the glacier during that melt season.

\section{Conservative mixing}

As defined by Equation (1), the mixing model assumes that the mass of solutes transported by the two flow components remains unchanged after they mix. Collins (1979) defended this assumption on the grounds that sedimentary particles in suspension retain significant quantities of ions adsorbed to their surfaces after they exit from the glacier portal. This is said to imply that solution and surface exchange between suspended load and meltwaters play only a minor role in modifying the composition of meltwaters once flow is in large channels. This conclusion is, however, contradicted by the fact that 
Table 1. Chemical composition (mean and standard error of the mean) of the three water types sampled from boreholes at Haut Glacier d'Arolla, Switzerland, in 1992. Concentrations of cations and anions are measured in micro-equivalents per litre. $E C_{0}$ is the electrical conductivity of the waters at $0^{\circ} \mathrm{C}\left(\mu \mathrm{S} \mathrm{cm}^{-1}\right) . S I_{\mathrm{cc}}$ is the saturation index for calcile and $p\left(\mathrm{CO}_{2}\right)$ is the partial pressure of carbon dioxide (atmospheres) with which the water appears to be in equilibrium. The latter two parameters are calculated from group mean data rather than individual sample analyses

\begin{tabular}{|c|c|c|c|}
\hline & Mode 1 & Mode 2 & Mode 3 \\
\hline Species & Mean S.E. & Mean S.E. & Mean S.E. \\
\hline
\end{tabular}

\begin{tabular}{lrrrrrr}
$\mathrm{Ca}^{2+}$ & 10 & 4.3 & 183 & 16.4 & 815 & 10.4 \\
$\mathrm{Mg}^{2+}$ & 6 & 3.2 & 17 & 1.4 & 90 & 1.4 \\
$\mathrm{Na}^{+}$ & 4 & 1.1 & 10 & 2.0 & 15 & 0.2 \\
$\mathrm{~K}^{+}$ & 2 & 0.5 & 13 & 3.7 & 16 & 0.2 \\
$\mathrm{HCO}_{3}$ & 9 & 17.1 & 166 & 26.7 & 596 & 10.0 \\
$\mathrm{Cl}^{-}$ & 4 & 1.0 & 4 & 0.7 & 5 & 0.3 \\
$\mathrm{NO}_{3}{ }^{-}$ & 5 & 4.4 & 6 & 3.0 & 27 & 0.2 \\
$\mathrm{SO}_{4}{ }^{2-}$ & 6 & 3.2 & 37 & 5.1 & 312 & 4.8 \\
& & & & & & \\
$\mathrm{pH}^{-6}$ & 6.4 & 0.1 & 8.5 & 0.6 & 7.5 & 0.1 \\
$\mathrm{EC}_{0}$ & 1.8 & 0.3 & 10.9 & 0.8 & 45.5 & 0.2 \\
$\mathrm{SI}_{c c}$ & 6.22 & & -1.62 & & -1.47 & \\
$-\log p$ & 2.66 & & 3.52 & & 1.96 & \\
$\left.\quad \mathrm{CO}_{2}\right)$ & & & & & & \\
\hline
\end{tabular}

bulk meltwaters are commonly undersaturated with respect to reactive minerals such as calcite (Raiswell, 1984; Brown and others, 1994), as are waters sampled at the glacier bed from boreholes (Table 1). In addition, laboratory weathering experiments involving suspended sediment which has passed through the drainage system of Haut Glacier d'Arolla (Brown and others, in press) show significant and continuing solute acquisition by deionized water placed in contact with sediment concentrations comparable to those recorded in melt streams over at least the first $3 \mathrm{~h}$ of contact (Fig. 1). Other experiments, which simulate the mixing of dilute and concentrated meltwaters, also reveal significant solute acquisition from suspended sediment after mixing (Tranter and others, 1989). If, as suggested earlier, mixing is not confined to the extreme terminal regions of the glacier, it is extremely unlikely to be conservative. Brown and others (in press) estimated that as much as $70 \%$ of the $\mathrm{Ca}^{2+}$ load transported by bulk meltwaters draining from Haut Glacier d'Arolla in August 1990 may have been acquired by post-mixing reactions.

To illustrate the significance of this point, we present the results of analyses of waters from 22 boreholes drilled through Haut Glacier d'Arolla in August-September 1992. Over 3000 measurements of electrical conductivity (EC) were made on these waters, and the resulting frequency distribution shows three clear modes. Samples of each water type were analyzed for their $\mathrm{pH}$ and major cation and anion composition (Table 1). The conven- tional mixing-model approach to glacier hydrology would make the assumption that waters of intermediate composition (mode 2) were produced by conservative mixing of more dilute (mode 1) and more concentrated (mode 3 ) waters. To determine whether our chemical data are consistent with this assumption, we used the multivariate mixing model SOLMINEQ88 (Kharaka and Barnes, 1973) to determine whether or not mixing was conservative for the full range of dissolved species analyzed. A mixture of nine parts mode 1 and one part mode 3 waters would have concentrations of $\mathrm{Mg}^{2+}, \mathrm{Cl}$, $\mathrm{NO}_{3}{ }^{-}$and $\mathrm{SO}_{4}{ }^{2-}$ which are comparable with those of mode 2 waters. However, such a mixture would contain significantly less $\mathrm{Ca}^{2+}, \mathrm{K}^{+}$and $\mathrm{HCO}_{3}{ }^{-}$, and have a lower $\mathrm{pH}, \mathrm{EC}$ and calcite-saturation index, and higher $p\left(\mathrm{CO}_{2}\right)$ than mode 2 waters. To reproduce these properties of mode 2 waters, it was necessary to simulate the dissolution of an additional $5 \times 10^{-5} \mathrm{moll}^{-1}$ of calcite and $8 \times$ $10^{6} \mathrm{moll}^{-1}$ of potash feldspar in the mixture. This clearly indicates that, for many dissolved species, it would be incorrect to assume that mixing of dilute and
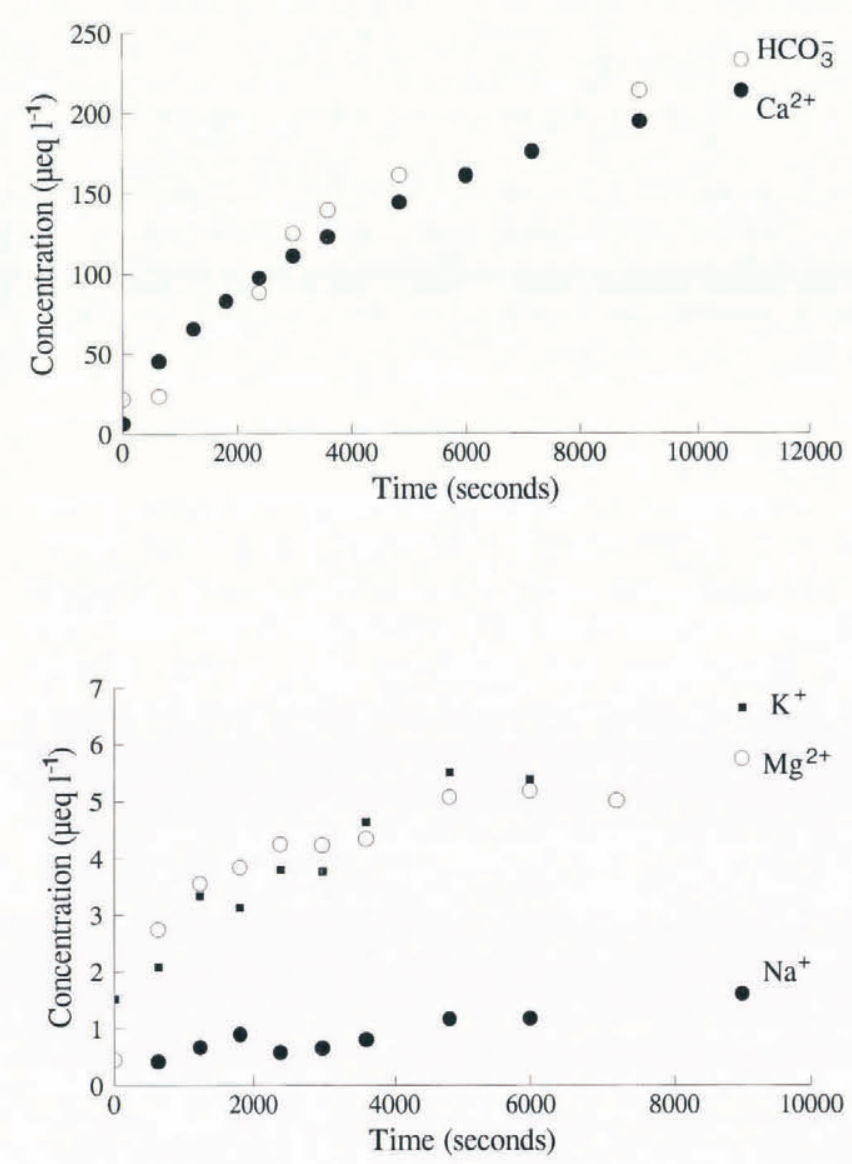

Fig. 1. (a) Concentrations of $\mathrm{Ca}^{2+}$ and $\mathrm{HCO}_{3}$ as a function of lime in a laboratory dissolution experiment using a water : rock ratio of $4 \mathrm{~g}^{-1}$. (b) Concentrations of $\mathrm{Mg}^{2+}, \mathrm{Na}^{+}$and $\mathrm{K}^{+}$as a function of time in a laboratory dissolution experiment using a water : rock ratio of $4 \mathrm{gl}^{-1}$. The sediment used in the experiment was collected from the margins of the main meltwater stream draining from Haut Glacier d'Arolla; the solvent was deionized water left in free contact with the atmosphere and stirred continuously for the duration of the experiment. 
concentrated waters is conservative. It may also be the case that mode 2 waters are not, in any event, produced by mixing of mode 1 and mode 3 waters, but that the three water types evolve independently along different flow paths with different residence times.

Nevertheless, it is useful for our present purposes to try to quantify the significance of violation of the assumption of conservative mixing. If we take the mean EC of mode 1 $\left(C_{\mathrm{e}}\right)$ and mode $3\left(C_{\mathrm{s}}\right)$ waters as a measure of their solute content (Table 1), and use Equation (1) to calculate the EC of mode 2 waters $\left(C_{\mathrm{t}}\right)$, we find that a $9: 1$ mixture of mode $1\left(Q_{\mathrm{e}}\right)$ and mode $3\left(Q_{\mathrm{s}}\right)$ waters would give $C_{\mathrm{t}}=6.3 \mu \mathrm{S} \mathrm{cm}^{-1}$. Mode 2 waters have a measured mean $\mathrm{EC}$ of $10.85 \mu \mathrm{S} \mathrm{cm}^{-1}$. If we then use this measured value as an estimate of $C_{\mathrm{t}}$, and take the mean values for mode 1 and mode 3 waters as estimates of $C_{\mathrm{e}}$ and $C_{\mathrm{s}}$, we can use Equation (2) to estimate $Q_{\mathrm{s}}$. We obtain a value of 2.1 instead of the true value of 1 . The results of similar calculations performed using concentrations of other dissolved species are presented in Table 2. Estimates of

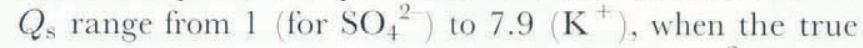
value (assuming conservative mixing for $\mathrm{SO}_{4}{ }^{2}$ ) is 1 . Thus, even if one accepts the validity of the basic mixingmodel approach to glacier hydrology, hydrograph separations which are based upon dissolved species for

Table 2. Results of mixing-model calculations performed using water compositions equivalent to the mean composition of each of the three water types sampled from boreholes at Haut Glacier d'Arolla in 1992. Mode 2 concentration refers to the observed solute concentration $\left(\mu e q \Gamma^{-1}\right)$ in waters of intermediate composition believed to form by mixing of dilute (mode 1) and concentrated (mode 3) waters wilh additional solute furnished by post-mixing reaction. Predicted $C_{\mathrm{t}}$ is the expected concentration of inlermediale waters formed by mixing nine parts mode 1 with one parl mode 3 waters with no post-mixing reaction. The percenlage of solute derived by post-mixing reaction is given by: (( Mode 2 concentration - Predicted $\left.C_{\mathrm{t}}\right) /$ Mode 2 concentration) $\times 100$. Predicled $Q_{\mathrm{s}}$ refers to the estimate of $Q_{\mathrm{s}}$ that would be obtained using Equation (2) if $Q_{\mathrm{t}}=10$ and the measured mean compositions of the three borehole-water types given in Table $I$ are used as estimates of $C_{\mathrm{e}}, C_{\mathrm{t}}$ and $C_{\mathrm{s}}$

$\begin{array}{ccccc}\text { Species } & \text { Mode con- } & \text { Predicted } & \% \text { solute } & \text { Predicted } \\ \text { centration } & C_{\mathrm{t}} & \text { from post- } \\ & & Q_{\mathrm{s}} \\ & & \begin{array}{c}\text { mixing re- } \\ \text { actions }\end{array}\end{array}$

\begin{tabular}{lrrrr}
\hline $\mathrm{Ca}^{2+}$ & 183 & 90 & 51 & 2.1 \\
$\mathrm{Mg}^{2+}$ & 17 & 14 & 13 & 1.3 \\
$\mathrm{Na}^{+}$ & 10 & 5 & 51 & 5.5 \\
$\mathrm{~K}^{+}$ & 13 & 3 & 73 & 7.9 \\
$\mathrm{HCO}_{3}{ }^{+}$ & 166 & 68 & 59 & 2.7 \\
$\mathrm{Cl}$ & 4 & 4 & 0 & 0.0 \\
$\mathrm{NO}_{3}{ }^{-}$ & 6 & 7 & 14 & 0.5 \\
$\mathrm{SO}_{4}{ }^{2}$ & 37 & 37 & 0 & 1.0 \\
& 11 & 6 & & \\
$\mathrm{EC}$ & 11 & & & 2.1 \\
\hline
\end{tabular}

which mixing is non-conservative may be very seriously in error.

Most previous mixing-model studies have based separations on the EC of meltwaters (e.g. Collins, 1978, 1979; Gurnell and Fenn, 1984). The results presented above suggest that $\mathrm{EC}$ is not a conservative property of glacial meltwaters and that this practice is therefore unreliable. Better estimates are more likely to be obtained if separations are based upon measurements of the concentration of conservative species such as $\mathrm{Mg}^{2+}$, $\mathrm{SO}_{4}{ }^{2}, \mathrm{Cl}$ and $\mathrm{NO}_{3}$. Of these species, $\mathrm{Mg}^{2+}$ and $\mathrm{SO}_{4}{ }^{2}$ are likely to be more useful than $\mathrm{Cl}$ and $\mathrm{NO}_{3}$ because the latter two species are normally derived primarily from the snowpack and will be preferentially leached from the catchment in the early part of the melt season (Tranter and others, 1993). This conclusion is consistent with the argument put forward by Tranter and Raiswell (1991) that $\mathrm{SO}_{4}{ }^{2-}$ may be the best species to use for mixing-model calculations.

\section{SUMMARY}

The application of mixing models to the investigation of flow routing of meltwaters in glaciers demands:

(a) Independent confirmation that the number of flow components included in the mixing model is appropriate for the glacier in question.

(b) More rigorous definition of the hydrological pathways associated with each flow component, so that interpretation of mixing-model results can be facilitated.

(c) Confirmation that the flow components identified have unique chemistries and selection of appropriate values for these. If component chemistries are not unique, it is necessary to evaluate how they vary over time.

(d) Determination of an appropriate solute species on which to base hydrograph separations in order to minimize the impact of violating the assumption of conservative mixing. The commonly used parameter, EC, is not conservative and is therefore inappropriate for this purpose.

At present, it is not clear that these requirements can actually be met and we therefore advocate restraint in the application of mixing models in glacier hydrology. We also believe that conclusions drawn from past applications are unreliable and that they do not provide a satisfactory basis for discussion of the functioning of glacier drainage systems.

\section{ACKNOWLEDGEMENTS}

We are grateful for grants from the U.K. Natural Environment Research Council GR3 7004a and GR3 8114). G.H.B. holds a NERC Fellowship GT5/F/91/ AAPS/13). M. Nielsen, M. Tully, C. Smart and S. Gordon made major contributions to our borehole studies in 1992. 


\section{REFERENCES}

Brown, G.H. and M. Tranter. 1990. Hydrograph and chemograph separation of bulk meltwaters draining the Upper Arolla glacier, Valais, Switzerland. International Association of Hydrological Sciences Publication 193 Symposium at Lausanne 1990-Hydrology in Mountainous Regions. I. Hydrological Measurements; the Water Cycle), $429-437$.

Brown, G. H., M. Sharp, M. Tranter, A. M. Gurnell and P. W. Nienow. 1994. Impact of post-mixing chemical reactions on the major ion chemistry of bulk meltwater draining the Haut Glacier d'Arolla, Valais, Switzerland. Hydrological Processes, 8, 465480.

Brown, G.H., M. Tranter and M. Sharp. In press. Experimental investigations of solute acquisition from suspended sediment by Alpine glacial meltwaters. Hydrological Processes.

Burkimsher, M. 1983. Investigations of glacier hydrological systems using dye tracer techniques: observations at Pasterzengletscher, Austria. J. Glaciol., 29 (103), $403-416$.

Collins, D. N. 1978. Hydrology of an Alpine glacier as indicated by the chemical composition of meltwater. Z. Gletscherkd. Glazialgeol., 13(1/2), 1977, 219-238.

Collins, D. N. 1979. Quantitative determination of the subglacial hydrology of two Alpine glaciers. J. Glaciol., 23 (89), 347-362.

Collins, D. N. 1982. Flow-routing of meltwater in an alpine glacier as indicated by dye tracer tests. Beitr. Geol. Schweiz. Hydrol., 28 2), 523 534.

Collins, D. N. and G.J. Young. 1981. Meltwater hydrology and hydrochemistry in snow- and ice-covered mountain catchments. Nord. Hydrol., $12(4-5), 319-334$.

Fenn, C. R. 1987. Electrical conductivity. In Gurnell, A. M. and M.J. Clark, eds. Glacio-fluvial sediment transfer; an alpine perspective. Chichester, etc., John Wiley and Sons, 377-414.

Fountain, A. G. 1993. Geometry and flow conditions of subglacial water at South Cascade Glacier, Washington State, U.S.A.; an analysis of tracer injections. f. Glaciol., 39(131), 143-156.

Gurnell, A. M. 1987. Suspended sediment. In Gurnell, A. M. and M.J. Clark, eds. Glacio-fluvial sediment transfer: an alpine perspective. Chichester, etc., John Wiley and Sons, 305-354.

Gurnell, A. M. and C. R. Fenn. 1984. Flow separation, sediment source areas and suspended sediment transport in a pro-glacial stream. Catena Supplement 5, 109-119.

Hock, R. and R. LeB. Hooke. 1993. Evolution of the internal drainage system in the lower part of the ablation area of Storglaciären, Sweden. Geol. Soc. Am. Bull., $105(4), 537-546$.

Humphrey, N., C. F. Raymond and W. D. Harrison. 1986. Discharges of turbid water during mini-surges of Variegated Glacier, Alaska, U.S.A. J. Glaciol., 32(111), 195-207.

Johannessen, M., T. Dale, E. T. Gjessing, A. Henriksen and R. F. Wright. 1977. Acid precipitation in Norway: the regional distribution of contaminants in snow and the chemical concentration processes during snowmelt. International Association of Hydrological Sciences Publication 118 (Symposium at Grenoble 1975-Isotopes and Impurities in Snow and Ice), 116-120.
Kharaka, Y.K. and I. Barnes. 1973. SOLMNEQ: solution-mineral equilibrium computations. U.S. Geol. Surv. Water Resources Paper 73-002.

Lecce, S.A. 1993. Flow separation and diurnal variability in the hydrology of Conness Glacier, Sierra Nevada, California, U.S.A. $\mathcal{f}$. Glaciol., $39(132), 216-222$.

Nienow, P. 1994. Dye tracer investigations of glacier hydrological systems. (Ph.D. thesis, University of Cambridge.)

Nienow, P., M. Sharp and I. Willis. In press. Dye tracer investigations at the Haut Glacier d'Arolla, Switzerland. II. Seasonal changes in the morphology of the subglacial drainage system. Earth Surface Processes and Landforms.

Nye, J.F. 1973. Water at the bed of a glacier. International Association of Scientific Hydrology Publication 95 (Symposium at Cambridge 1969 Hydrology of Glaciers), 189-194.

Oerter, H., H. Behrens, G. Hibsch, W. Rauert and W. Stichler. 1980. Combined environmental isotope and electrical conductivity investigations of the runoff of Vernagtferner (Oetztal Alps). Mater. Glyatsiol. Issled. Khron. Obsuzhdeniya 39, 157-161.

Pinder, G. F. and J. F. Jones. 1969. Determination of the ground-water component of peak discharge from the chemistry of total runoff. Water Resour. Res., 5 (2), 438445.

Raiswell, R. 1984. Chemical models of solute acquisition in glacial melt waters. 7. Glaciol., 30 (104), 49-57.

Röthlisberger, H. 1972. Water pressure in intra- and subglacial channels. J. Glaciol., 11 162$),$ 177-203.

Seaberg, S. Z., J. Z. Seaberg, R. LeB. Hooke and D. W. Wiberg. 1988. Character of the englacial and subglacial drainage system in the lower part of the ablation area of Storglaciären, Sweden, as revealed by dye-trace studies. J. Glaciol., 34(117), 217-227.

Sharp, M. 1991. Hydrological influences from meltwater quality data: the unfulfilled potential. Proceedings of the British Hydrological Society 3rd National Symposium, Southampton, 16-18 September 1991, 5.1-5.8.

Shoemaker, E. M. 1986. Subglacial hydrology for an ice sheet resting on a deformable aquifer. J. Glaciol., 32(110), 20-30.

Tranter, M. and R. Raiswell. 1991. The composition of the englacial and subglacial component in bulk meltwaters draining the Gornergletscher. 7. Glaciol., 37(125), 59-66.

Tranter, M., R. Raiswell and R.A. Mills. 1989. Chemical weathering reactions in Alpine glacial meltwaters. In Miles, D. L., ed. Proceedings of the 6th International Symposium on Water-Rock Interaction, Malvern, 1989. Rotterdam, Balkema, 687-690.

Tranter, M., G. Brown, R. Raiswell, M. Sharp and A. Gurnell. 1993. A conceptual model of solute acquisition by alpine glacial meltwaters. f. Glaciol., 39 (133), 573-581.

Walder, J.S. 1986. Hydraulics of subglacial cavities. f. Glaciol., 32(112), 439445.

Walder, J.S. and A. Fowler. 1994. Channelized subglacial drainage over a deformable bed. f. Glaciol., 40 (134), 3-15.

Weertman, J. 1972. General theory of water flow at the base of a glacier or ice sheet. Rev. Geophys. Space Phys., 10 1), 287-333.

Willis, I. C., M.J. Sharp and K. S. Richards. 1990. Configuration of the drainage sytem of Midtdalsbreen, Norway, as indicated by dyetracing experiments. J. Glaciol., 36 (122), 89-101. 